\title{
Transposition
}

Musique et Sciences Sociales

$7 \mid 2018$

Le prix de la musique

\section{Teresa Cascudo (ed.), Nineteenth-Century Music \\ Criticism}

Turnhout, Brepols, 2017.

\section{Marica Bottaro}

\section{OpenEdition}

\section{Journals}

Electronic version

URL: http://journals.openedition.org/transposition/2613

DOI: 10.4000/transposition.2613

ISSN: 2110-6134

Publisher

CRAL - Centre de recherche sur les arts et le langage

\section{Electronic reference}

Marica Bottaro, "Teresa Cascudo (ed.), Nineteenth-Century Music Criticism », Transposition [Online], 7 | 2018, Online since 15 September 2018, connection on 25 September 2020. URL : http://

journals.openedition.org/transposition/2613; DOI : https://doi.org/10.4000/transposition.2613

This text was automatically generated on 25 September 2020.

\section{cc) (†) (2)}

La revue Transposition est mise à disposition selon les termes de la Licence Creative Commons Attribution - Partage dans les Mêmes Conditions 4.0 International. 


\section{Teresa Cascudo (ed.), Nineteenth- Century Music Criticism}

Turnhout, Brepols, 2017.

Marica Bottaro

\section{REFERENCES}

Teresa Cascudo (ed.), Nineteenth-Century Music Criticism, Turnhout, Brepols, 2017.

1 This volume contains a selection of papers presented at the International Conference on Nineteenth-Century Music Criticism organized by the Centro Studi Opera Omnia Luigi Boccherini (Lucca) and Palazzetto Bru Zane (Venice), in collaboration with OICRM (Montréal). The conference was attended by nearly fifty researchers from all over the world, and took place at the Complesso Monumentale di San Micheletto in Lucca from 10 - 12 November, 2015.

2 Nineteenth-Century Music Criticism is the third of five volumes in the Music, Criticism \& Politics series, edited by Luca Lévi Sala and supported by the Centro Studi Opera Omnia Luigi Boccherini. The series explores the relationship between music and politics from the Seventeenth Century to the present day, whilst also looking at the study of music criticism, pamphlets, and the press as mechanisms for expressing and exercising cultural power. The edition of Nineteenth-Century Music Criticism is excellently presented. It has a clear, compact design, good quality images and musical examples (black and white). There is a detailed bibliography at the end of each article, as well as helpful abstracts of each essay (in English), author biographies, and finally an index of names. The volume's editor, Teresa Cascudo García-Villaraco, has shown excellent attention to detail throughout.

The cover image is of a fetching caricature of the Spanish composer, music critic and bullfighter, Antonio Peña y Goñi (1846-1896) - quoted on several occasions in the essay, Graphic Humour as Musical Criticism by José Ignacio Suárez García. The caricature is by the Spanish illustrator and painter, José Cuchy Arnau (1860-1936). It is taken from the 
cover of the humorous and satirical review, La Semana Cómica, dated 30 July 1888 . The caricature portrays Peña y Goñi in the double role of music critic and bullfighter: his right hand is holding a quill, while his left hand grabs the muleta, the stick tied to a red cloth used in the final third of a bullfight. Italian and German) covering music criticism and press coverage in the long Nineteenth Century in Europe and America. The essays take us from London to New York, Paris to Rio de Janeiro, Vienna to Montevideo, Strasbourg to Buenos Aires, passing through Spain, Germany and Italy. The time frame stretches from the Mémoires of André-Ernest-Modeste Grétry (1741-1813) up to articles written by Manuel de Falla in Madrid during World War I.

6 The articles testify to the explosion of music criticism in the Nineteenth Century. It is widely agreed that the figure of the music critic is officially born out of this flourishing historical period, with music gaining an important place in many newspapers and periodicals throughout the century. News and reviews of musical life play a central part in the music market; indeed, the success (and failure) of this trade depends on the quantity and nature of information circulating about musical events, performers and new repertoires. Music's greatest treatment in the press is in the emerging phenomenon of music criticism, whose format is pertinent and lengthy essays. These texts can influence the readers/listeners' opinion to the point of significantly influencing fashions and cultural currents. The articles contained in this volume aim to highlight the relevance and value of music criticism and press coverage for today's musicology. This in turn will lead to a greater understanding of an animated, fervent and contradictory period like the Nineteenth Century.

7 The twenty-two articles are divided into three sections: Music Criticism / Music Journalism, Discourses, and Composers' Voices. This division does not preclude referencing between essays in different sections. Essays often complete each other, providing a broad overview of the central theme of Nineteenth-Century music criticism.

us now examine the essays in detail, including the volume's Introduction by its curator, Teresa Cascudo García-Villaraco, who is also the author of an article in the second section of this miscellany ${ }^{1}$.

Divided into three parts, the first section of the Introduction discusses the birth and development of music criticism as a genre, highlighting, in particular, developments in the discipline in recent years. The second part considers the impact of studying reception and the benefits of Norman Fairclough's Textual Analysis for Social Research theory, by reflecting on its relevance for a greater understanding of the phenomenon of music criticism ${ }^{2}$. This leads on to a discussion of the plurality of meanings for the term 'criticism,' and on the links made by Cultural transfer studies. This second part of the introduction ends by considering the change brought about by the 'massive digitization of historical newspapers, including musical periodicals' to the way we use newspapers as a source of research for the history of music. ${ }^{3}$ In the third part, Cascudo briefly reviews all the articles in the three sections of the volume, which we will now consider in turn.

10 The opening essay in the section entitled Music Criticism / Music Journalism, as well as in the volume itself, is by Katharine Ellis, the world's foremost expert on Nineteenth- 
Century French music criticism. ${ }^{4}$ It is no coincidence that Cascudo has chosen to open with this article, as Ellis devotes much of her study to a solid and stimulating theoretical elaboration, which merits detailed analysis here.

11 In her introduction, Ellis illustrates the evolution of music criticism as a genre (technological innovations, the growth of cultural and reception history etc.) followed by a section that refers to speech acts by John Searle and John Austin ${ }^{5}$. To understand or restrict the range of possible meanings of a set of words, as Ellis underlines, it is necessary to know its rules and implications. The main thesis of speech acts is based on the assumption that social context and the speaker's intention influence the communication of meaning within the discourse. Without this context, according to Jacques Derrida, 'all writings [are] (as) 'orphan' texts'6. Ellis argues that it is therefore preferable that scholars of music criticism reconstruct the overall framework discussed by experts in language.

Ellis continues with a section dedicated to general contracts, which are indispensable when working on music criticism. Indeed, the readers of periodicals had specific expectations about the material they had access to, and these expectations were born out of both the present and the past. The readers knew what was happening around them, but had also read certain magazines for many years. Our task as scholars, therefore, is to enter the world of readers in order to reconstruct their expectations. The article continues with the section Genres of Music Criticism. Here, the author reviews the variety of genres of music criticism by examining the characteristics of different types of articles in the weekly music magazines.

13 The last part of the essay affirms and underlines the absolute necessity of contextualizing the texts. To this purpose, Ellis offers two examples from her field of study, French music criticism of the Nineteenth Century. The first case concerns two festivals: the Wagnerian one in Bayreuth and the 'national' one in Dijon, discussed in several articles in the Parisian press (during the summer of 1876). The other example dates from January 1891 and deals with the absence of Wagnerian plays on the Parisian stage and the première of Thermidor, a dramatic play by Victorien Sardou. Ellis shows how in both cases it is necessary to reconstruct the context and make use of the theory of linguistic acts and generic contracts in order to grasp fully the review's content. The author then cites Berlioz as an example to emphasize that even a critic of his stature was not always reliable and could produce biased articles. There were, however, cases in which critics were sincere, and Ellis calls us to extract the rules of the author's rhetoric from these texts and better interpret linguistic theory. Ellis concludes by saying that analysing music criticism requires us to move easily between three disciplines, namely musicology, literary studies and history. These three fields of study make the press 'an exciting intersection of ideas', in which music criticism represents 'a veritable salon in print form.'

In the subsequent article by Guillaume Bordry, the three fundamental elements of the author's approach are provided in the title: criticism, claque and réclame $e^{8}$ These are considered in reference to Les Soirées de l'orchestre (1852) by Hector Berlioz and, in particular, to the seventh and eighth soirées. As well as highlighting Berlioz's interest in a certain kind of subject, Bodry attempts to show how the phenomenon of the claque (already in use in Roman times and still common in the Nineteenth Century), the réclame, and criticism (in the press) influenced public taste and determined the success or failure of a composition or indeed an artist. 

for the Revue et Gazette musicale de Paris on the Universal Exhibitions in Paris of 1867 and $1878^{9}$. The author highlights Monter's considerable difference of approach in relation to other nations, and their musical production, compared to France. This serves to deepen our understanding of the concepts of music and race in the period between these two Universal Exhibitions. Kahan uses accurate reconstruction to reveal the series of circumstances that prompted Monter to pass from a strong nationalist position to a broader, more open vision of 'world music'.

In his article, Ingeborg Zechner argues that opera production should be considered a transnational phenomenon, going beyond geographical boundaries. He claims that research in the field of opera should not limit itself to national studies, but instead consider its vast international market ${ }^{10}$. Zechner demonstrates in particular that foreign music criticism of Italian operatic performances played in London can provide a broader and more truthful vision compared to that of a local critic of the city's operatic scene. Indeed, critics from abroad bore witness to an aesthetic experience altogether different from the one they were used to. For this reason, they were able to provide fresh information and points of view to reconstruct the socio-cultural context of the time. Zechner offers a selection of examples of reviews of some works made explicitly for London by Italian, French, German and Austrian magazines. He looks at the representation of works that had been rearranged for the London opera market, as well as the nature and response of the opera's audience.

Jeroen Van Gessel analyses nearly three decades of operatic reviews from Strasbourg whilst identifying the problems inherent in his sources ${ }^{11}$. Divided into six parts, his article bases its raison d'être on a consideration by the German sociologist, Niklas Luhmann, according to whom the use of the media as a source of information puts us in a doubly critical position..$^{12}$ If, on the one hand, we rely on the media to obtain data, on the other, we cannot be entirely certain that it is reliable. However, what is undoubtedly possible to grasp from these sources, specifically from operatic reviews, is the opinion that the press held of its own role and its relations with theatre managers, artists and the public. Van Gessel reveals in a stimulating way the extent to which criticism can provide relevant information on the very authors of that criticism.

José Ignacio Suárez García traces the reception of Wagnerian production and aesthetics in Spain in the last decades of the Nineteenth and the early Twentieth Centuries using a rich iconographic apparatus of ironic vignettes. ${ }^{13} \mathrm{He}$ employs humorous vignettes that appeared in various Spanish periodicals of the period, which provide also a way 'to laugh and to think, for both fun and reflection. ${ }^{14}$ The temporal distance separating today's readers from the time when the cartoons were produced prompts José Ignacio Suárez García to rebuild their cultural context, allowing all the facets and references that the cartoonists took for granted to become more apparent. In this case, the caricatures criticized not only the system of Wagnerian musical dramas, but also the contents of the librettos (considered excessively 'Germanic'), as well as the orchestra directors, performers, etc. This gave rise to a well-rounded criticism of Wagnerian fashion that famously hovered over Europe at this time.

Mónica Vermes unexpectedly transports us to late Nineteenth-Century Brazil, and in particular Rio de Janeiro, with a long and comprehensive article dedicated to the musical life of the city ${ }^{15}$. The author deals mainly with articles published in the $O$ Paiz newspaper, giving special attention to symphonic concerts. Mónica Vermes's study 
identifies three conflicting forces operating at the time. The first was a group of musicians inspired by the imperial period. Their reference figure was the composer, Antonio Carlos Gomes, and their main proponent was the critic, Oscar Guanabarino. The second was a group of musicians who had been at the centre of the musical scene since the Republic's proclamation in 1889. They were responsible for the National Institute of Music, the nation's most important educational institution. Finally, there was the rise of a real entertainment industry focused in particular on the publication of music sheets and on theatrical activity. In short, the press allows us to glimpse what the musical life of late Nineteenth-Century Rio was really like, and, as in many other large cities, it was conditioned and 'shaken' by technological developments.

Marita Fornaro Bordolli transports us to the capital of Uruguay with an in-depth article on the first thirty years of the periodical, Montevideo Musical. ${ }^{16}$ This is the first study of its kind in this country, rendering the analysis of Uruguayan music criticism all the more significant. The author divides the article into distinct sections. She begins with the topic of the press in Uruguay, before discussing the Uruguayan music press of the Nineteenth Century, and then examining the Montevideo Musical periodical in a period of particularly strong Italian musical influence in Uruguay. The following section is dedicated to the ideology and themes in Montevideo Musical, which in turn is divided into several detailed paragraphs concerning the subjects dealt with in the magazine. The article ends by highlighting the driving role of Montevideo Musical in shaping Uruguayan music culture, demonstrating how significant the contribution of music criticism can be to the cultural development of a nation.

The second section of the volume is entitled Discourses.

Our journey through South America continues to Argentina. Melanie Plesch's essay looks at the weekly magazine, Boletin Musical, published in Buenos Aires between August and December $1837^{17}$. This is the first magazine dedicated to music in Argentina, and is still available today, giving Plesch's article a certain historiographical value. Each number contains one or more compositions, printed by the Litografía Argentina, owned by Gregorio Ibarra, and some literary booklets printed by the Argentina Printing Press (Imprenta Argentina). Plesch attempts to outline the 'cultural biography' of the Boletin Musical. She does so by considering the magazine as an 'object' based on the concept of 'social lives' put forward by Arjun Appadurai and Igor Kopytoff, in which an object's meanings are related to the different cultural values bestowed upon it in precise moments of its "biography. ${ }^{18}$

23 Erin Fulton's chapter takes us to New York in the first half of the Nineteenth Century where several attempts were made to create a permanent opera house for foreign works ${ }^{19}$. The difficulty in achieving this was often due to financial problems or existing prejudices against theatrical activities. An example of a contrasting narrative to these justifications, however, is the huge success of opera sung in English in this period. Fulton effectively demonstrates that the aversion to foreign opera was linked to debates about the moral and political influence of European culture on the New World. In fact, the author uses the journal articles to show how they propagated the idea that opera represented a threat because it was a foreign product.

In what Marc Ernesti calls the 'philological microscope', the author examines a single year of the Napoleonic period (1813) in two German-language music magazines, Allgemeine musikalische Zeitung (Lipsia) and Wiener allgemeine musikalische Zeitung $(\text { Vienna })^{20}$. Debate on cultural identity was rife at this time, and many composers tried 
to uphold the Germanic paradigm above all others, and against the 'invasion' of foreign music. Using a mainly inter-textual approach, Ernesti highlights the contact points between the two magazines and from them extrapolates the editorial strategies of the German music media in the early Nineteenth Century.

Nancy November explores the genre of the string quartet at the dawn of the Nineteenth Century in Vienna, in particular, using reviews by music critics relating mainly to their performances ${ }^{21}$. This was a turning point for the genre, when the string quartet gained a place on the stage and abandoned the private setting of courts and salons. It was precisely this change that saw the emergence of a group of critics specialized in the subject, its musicians and its intrinsic meanings. This led gradually to the formation of a genuine canon for the string quartet. Nancy November goes on to find a dualism in criticism that is intrinsic to the genre: paying attention contemporaneously to the moment of the performance (the representation), and to the score (the will of the composer).

With Maria Teresa Arfini, we move to Germany and on to the ideas of the musicologist, music theorist and music critic, Adolf Bernhard Marx ${ }^{22}$. Marx presented a personal theory on the meaning of music in his articles, outlining the concept of the Grundidee (fundamental idea) that would allow us to understand compositions in their entirety. Marx focused mainly on Beethoven's oeuvre, and in particular on the cantata Meeresstille und glückliche Fahrt Op. 112, which used a text by Goethe. Marx deemed the music inadequate at expressing the meaning of Goethe's words. He contrasted 'Beethoven's failure' with the successful instrumental music of Mendelssohn's concert overture based on the same pair of poems by Goethe, Meeresstille und glückliche Fahrt, in D major, Op. 27. Unlike Beethoven, who had used text as well as sounds, Mendelssohn had succeeded in expressing the Grundidee of the immortal poet through sounds alone.

In the only article in the volume to focus solely on Italy, Renato Ricco effectively illustrates Giacomo Leopardi's ideas on music through the poet from Recanati's literary production. ${ }^{23}$ Ricco highlights the modernity of Leopardi's aesthetic thought, especially given the dearth of literature on the subject on the Italian peninsula at this time. Particularly surprising is Leopardi's attention to some properties of sound - such as the 'mere' acoustic and timbre effect - which will be elevated to primary parameters of musical composition during the Twentieth Century. The synesthetic quality of the poet's thought, which does not shy from exploring the effects of sounds, tastes and colours, is also remarkable.

Through a close reading of critical articles taken from periodicals from different nations, Žarko Cvejić explores the thorny conflict between the emergence of instrumental music as an independent and elevated art form and the birth of the phenomenon of instrumental virtuosity at the beginning of the Nineteenth Century. ${ }^{24}$ With the theorists of German Romanticism, instrumental music famously assumed a superior and almost spiritual value, compared to music with extra-musical references. This was especially true in the writings of E. T. A. Hoffmann, who defined instrumental music as the "most romantic of the arts. ${ }^{25}$ Following this argument, nothing could be further from the human physicality of the great, talented men of the early Nineteenth Century (for example, Paganini, Liszt, Thalberg etc.). Cvejić shows the gradual transition, from an initial fascination to a general mistrust, even total rejection, of transcendental virtuosity, accusing it of 'humanly' degrading an art with celestial connotations. 

criticism, the Czech, Eduard Hanslick ${ }^{26}$. Ward refers in particular to Hanslick's aesthetic theory of formalism. This set itself in opposition to programme music, since it was based on the principle of musical asemanticity. A more in-depth study on Hanslick shows that his philosophical ideas were anything but absolute. In fact, his formalism supported German nationalist ideology, which, as Ward points out, was linked to the use of gender, or more precisely sexist, rhetoric. The author discusses Hanslick's private life, and his Jewish origins on his mother's side, which he tried to hide throughout his life. Ward observes the apparent contradiction here of a person of Jewish origins supporting German (and anti-Semitic) nationalism. This was indeed a stratagem on Hanslick's part. Considering the fact that he often links effeminacy to Judaism in his writings, Hanslick's aim with his gender rhetoric is to divert the attention of his readers and the wider public away from his own origins.

We are then transported to early Twentieth-Century Spain. In her essay, Teresa Cascudo García-Villaraco discusses the writings of the composer, Manuel de Falla, which have already been extensively investigated by other critics. She focuses in particular on four articles published in Madrid in 1916, during the First World War, and employs the 'philological microscope' mentioned by Marc Ernesti in his article. ${ }^{27}$ Having been forced to leave Paris and return home, Falla wrote his articles in Madrid, and immersed himself completely in this stormy context. Cascudo extrapolates the most significant topics contained in Falla's articles, highlighting the composer's ability to present himself as an exponent of modern music without completely turning his back on the past and, above all, without opposing himself to the pre-established (and conservative) order. Dealing with themes such as race, patriotism, nationalism, Europe and war, his writings bear witness to the changes taking place both Spain in general, and in particular its musical life.

R. J. Arnold explores the writings of André-Ernest-Modest Grétry. ${ }^{28}$ Grétry was one of the first musicians willing to present the problems of musical composition to a large audience, rather than just to specialists. His texts were eclectic in nature, dealing with personal experiences, but also technical problems related to music, as well as a broad spectrum of issues from politics, philosophy, religion and so on. He helped to create the language and form through which music would be investigated 'in written words' during the Nineteenth Century.

Diau-Long Shen devotes his article to the influence of Mozart's work on the critic and composer, E. T. A. Hoffmann. ${ }^{29}$ In his reviews of Mozart's works, Hoffmann outlined the ideas he had drawn from them so as to continue with the process of building a Germanic cultural identity. Indeed, according to Hoffmann, it was Mozart who had first defined German Romantic opera. Hoffmann admired in particular the imagination and irony of the Austrian musician's operatic compositions. He also provided a new interpretation of the relationship between early Romanticism and irony. By including the views of other German critics in addition to Hoffmann, Shen offers a new perspective from which to evaluate Mozart's work in the history of the German operatic genre.

34 The scholar, Anja Bunzel presents a well-organized text on the German musician, composer, teacher and writer, Johanna Kinkel (1810-1858). ${ }^{30}$ She opens with an indepth analysis of Kinkel's life before moving on to her opinions on issues of gender. The 
following section is dedicated to the reception of her first Lieder Op. 7 (1838), reviewed with great enthusiasm by critics such as Ludwig Rellstab, Gottfried Wilhem Fink and Oswald Lorenz. Bunzel then focuses on the Trinklied für Männerchor, sent by Kinkel to Robert Schumann to be published in the Neue Zeitschrift für Musik. Some critics' reviews, however, including those of Schumann, consistently demonstrated a certain prejudice against the female gender. Kinkel's music can therefore not be evaluated objectively through the critiques of her works during her lifetime. Bunzel continues with the examination of two other songs on the subject of drinking, written by Kinkel, Wasser und Wein, Op. 6 n. 1 (August Kopisch) and Trinklied im Sommer (Emanuel Geibel), comparing them to previous compositions. In the final section, the author relates some negative reviews of the latest compositions by Kinkel.

In his article, Yaël Hêche investigates Wagner's aesthetic evolution through the German musician's articles on La Reine de Chypre by Fromental Halévy ${ }^{31}$. Hêche reveals that Wagner's views on certain subjects were already anticipated in the articles he wrote on Halévy's grand opera. These included his accusation that the composer and poet did not collaborate, his praise of poetry and condemnation of series of historical booklets, and his denigration of Parisian theatrical institutions. His articles on Halévy thus represented a pretext to expose his new aesthetic, at this moment of change.

We remain with Wagner for the chapter by Rainer Kleinertz. The author focuses on the German composer's open letter on the innovative symphonic poems by Franz Liszt ( Über Franz Liszt's Symphonische Dichtungen), published in 1857 in the Neue Zeitschrift für Musik. ${ }^{32}$ As Kleinertz notes, the letter was considered a sort of 'advertisement' on the part of Wagner for his friend, Liszt. In reality, there was more to it. The content of the letter on Lisztian symphonic poems embodies the moment of decisive passage from the Ring to Tristan und Isolde. Indeed, as Kleinertz reminds us, Wagner had come into contact with Liszt's symphonic poems in Switzerland in 1856, and at the end of that year he wrote the first sketches of Tristan (so with Liszt's compositions still in mind). A few months later, in 1857, he published the essay on the innovations of Liszt's symphonic poems in the form of an open letter addressed to Marie von SaynWittgenstein. As Kleinertz reminds us, after Siegfried's second act, in August 1857, the German composer set aside the Ring and began to work extensively on Tristan und Isolde. This decision has often been considered to be the result of personal and financial problems, but this letter bears witness rather to the change of direction in Wagnerian aesthetics. For him, the symphonic poems represented real innovation, a new way of conceiving the form, far from that of the 'dated' sonata. The composer's letter therefore represents, albeit not openly, a manifesto of his aesthetics 'in progress'.

37 After reviewing all the essays of this volume, we must acknowledge the huge amount of work that Cascudo has put into it. As well as editing the book, she also wrote the 'Introduction' and the chapter on Manuel de Falla. The sheer number of studies included and the specificity of their subject matter make the volume extremely useful for specialists, while non-professionals may find the imposing mass of information provided difficult to navigate. Almost all of the authors make use of the extremely precise and timely concept of the 'philological microscope,' put forward by Marc Ernesti, to examine the 'veritable salon in print form,' evoked by Ellis, and to reproduce it before the reader's eyes.

To conclude, it is now evident that music criticism studies is finally opening up to other fields. Researchers now recognise not only the necessity of a multidisciplinary 
approach, but also the fundamental importance of reconstructing the context in which a critique was written in order to understand its content and relevance. As this volume encompassing different continents demonstrates, a cross-national point of view is nowadays as essential as a comparative methodology. Although the articles are set in various countries, they repeatedly underline the need for a wider perspective, both to connect them and highlight their commonality.

The heterogeneity and sheer variety of the approaches and subjects contained in this volume, as well as the quality of the scholarship throughout, provide a stimulus to increase and develop the study of Nineteenth-Century music criticism. The work represents a valuable advance in the construction and consolidation of the field, promising soon to become one of its most important bibliographic references.

\section{NOTES}

1. "Introduction", p. IX-XXIV.

2. FAIRCLOUgh Norman, Analysing Discourse: Textual Analysis for Social Research, London-New York, Routledge, 2003.

3. "Introduction", p. XVI.

4. "Music Criticism, Speech Acts and Generic Contracts", p. 3-21.

5. AUSTIN John Langshaw, How To Do Things with Words, URMson, James O., SBISÀ, Marina (ed.), Cambridge (MA), Harvard University Press, 1975. SEARLE John R., Expression and Meaning: Studies in the Theory of Speech Acts, Cambridge, Cambridge University Press, 1979. SEARLE, John R., Speech Acts, An Essay in the Philosophy of Language, Cambridge, Cambridge University Press, 1989.

6. Quoted in "Music Criticism, Speech Acts and Generic Contracts", p. 6.

7. Ivi, p. 19.

8. "Barnum et les Romains: Critique, claque et réclame dans les Soirées de l'orchestre d'Hector Berlioz", p. 23-32.

9. “A Critic's Progress: Émile-Mathieu de Monter's Musical Reporting of the Paris 1867 and 1878 Exposition Universelles for the Revue et Gazette musicale de Paris", p. 33-58.

10. "London's Italian Opera as a Topic of Interest to International Nineteenth-Century Music Criticism", p. 59-75.

11. "Speaking for Whom? Using Opera Reviews from Strasbourg (1887-1918) to Clarify the Problematical Source Character of Music Criticism", p. 77-100.

12. LUHMAnN Niklas, Die Realität der Massenmedien, Wiesbaden, Westdeutscher Verlag, 1996.

13. "Graphic Humour as Musical Criticism: Cartoon and Caricature in the First Wagnerian Reception in Madrid", p. 101-132.

14. Ivi, p. 101.

15. "The Music in the Theatres of Rio de Janeiro (1890-1900): Concert Series, Music Criticism and Conflicting Cultural Projects in the Early Years of the Republic", p. 133-158.

16. "The Power of Music Criticism in the Shaping of Modern Uruguay: An Analysis of the Newspaper Montevideo Musical", p. 159-180.

17. "The Cultural Biography of a Music Periodical: Boletín Musical (Buenos Aires, 1837)", p. 183-206. 
18. Ivi, p. 183. APPADURAI Arjun (ed.), The Social Life of Things: Commodities in Cultural Perspective, Cambridge-New York, Cambridge University Press, 1986 : see in particular корүтоғF Igor, "The Cultural Biography of Things: Commoditization as Process", p. 64-91.

19. "Nativist Rhetoric in the Opera Journalism of Antebellum New York City", p. 207-236.

20. "Vienna, and a Re-print of the AmZ: Notes on Intertextuality in German Music Media around 1800 ", p. 237-254, p. 238.

21. “The String Quartet in Early Nineteenth-Century Performance and Criticism”, p. 255-267.

22. "Beethoven e Mendelssohn nel pensiero di Adolf Bernhard Marx", p. 269-280.

23. “"La musica non imita e non esprime che lo stesso sentimento in persona»: per una (mancata) teoria musicale leopardiana", p. 281-303.

24. "Fallen Angels of Music: Subjectivity in Early $19^{\text {th }}$-Century Philosophy and the Reception of Virtuosity in Contemporary Music Criticism", p. 305-336.

25. Hoffmann E. T. A., "Beethoven's Instrumental Music”, charlton David (ed.), E. T. A. Hoffmann's Musical Writings: Kreisleriana, The Poet and the Composer, Music Criticism, Cambridge, Cambridge University Press, 1989, p. 96.

26. “'Absolute' Philosophy? Gender, Nationalism, and Jewishness in Eduard Hanslick's Formalism", p. 337-354.

27. "Manuel de Falla at War: On race, Sound and New Music", p. 355-376.

28. “«Les Plaisirs de l'Imagination Sont les Seuls Réels»: Grétry’s Writings and the Expansion of Critical Thought at the Beginning of the Nineteenth Century", p. 379-402.

29. “Composer-Critic and «Inimitable Creators»: E. T. A. Hoffmann, W. A. Mozart, and the Genesis of German Romantic Opera”, p. 403-419.

30. "Critical Responses to Nineteenth-Century Music Criticism: Johanna Kinkel's Trinklieder and Her Later Lieder Collections", p. 421-447.

31. "Richard Wagner et La Reine de Chypre de Fromental Halévy (Paris, 1841): la critique musicale comme réflexion esthétique capitale", p. 449-472.

32. "Richard Wagners offener Brief über Franz Liszts Symphonische Dichtungen (1857) und die Komposition von Tristan und Isolde", p. 473-493.

\section{AUTHORS}

\section{MARICA BOTTARO}

After completing a Saxophone Diploma, Marica Bottaro graduated in Musicology at Ca' Foscari University in Venice. In April 2017 she received her PhD, after completing a joint PhD program at Ca' Foscari University in Venice and the Université Paris 8. Her main research interests include French and Italian music of the 19th century and the beginning of the 20th century, with specific interests in nationalistic movements and music criticism. She also works on film and stage music, paying particular attention to the problems connected with orchestration. She has won several research grants from different countries (Italy, France, Switzerland). She is currently an Adjunct Professor in History of Music at the Academy of Fine Arts, Bologna (Italy), and Cultore della materia at $\mathrm{Ca}^{\prime}$ Foscari University in Venice. 